\title{
Co-Culture of Trichoderma Reesei, Talaromyces Sp. and Aspergillus Spp. Produces A Multi-Enzyme Cocktail for the Hydrolysis of Sugarcane Bagasse Pretreated with Piperonilic Acid (PIP) and Methylenedioxycinnamic Acid (MDCA)
}

\author{
Yuri Heck da Silva \\ Universidade de São Paulo: Universidade de Sao Paulo \\ Tássio Brito de Oliveira \\ Universidade Federal da Paraíba: Universidade Federal da Paraiba \\ Matheus Sanitá Lima \\ University of Western Ontario: Western University \\ Thiago Machado Pasin \\ The University of Texas at San Antonio \\ Ana Silvia de Almeida Scarcella \\ Universidade de São Paulo: Universidade de Sao Paulo \\ Maria de Lourdes Teixeira de Moraes Polizeli \\ Universidade de São Paulo: Universidade de Sao Paulo \\ Carlos Alberto Martinez \\ Universidade de São Paulo: Universidade de Sao Paulo \\ Marcos Silveira Buckeridge \\ Universidade de Sao Paulo Campus de Sao Paulo: Universidade de Sao Paulo \\ Wanderley Dantas dos Santos \\ Universidade Estadual de Maringa \\ Rosymar Coutinho de Lucas ( $\nabla$ rosymar_lucas@hotmail.com ) \\ UFJF: Universidade Federal de Juiz de Fora https://orcid.org/0000-0001-8738-7372
}

\section{Research Article}

Keywords: co-culture, second generation ethanol, sugarcane bagasse, Trichoderma reesei, Aspergillus sp., Talaromyces sp.

Posted Date: January 24th, 2022

DOI: https://doi.org/10.21203/rs.3.rs-1218029/v1

License: (c) (i) This work is licensed under a Creative Commons Attribution 4.0 International License. Read Full License 


\section{Abstract}

PURPOSE: The global energy matrix is primarily based on fossil fuels and alternatives for the production of renewable energy are necessary. The second-generation ethanol ( $2 \mathrm{G}$ ethanol) is such alternative. $2 \mathrm{G}$ ethanol is produced through the fermentation of sugar released from the enzymatic hydrolysis of lignocellulosic biomass. However, this process is still costly. Improvements should include the use of less expensive biomass pretreatments and enzymatic cocktails produced by the co-cultivation of filamentous fungi.

METHODS: For the production of synergistic holocellulolytic enzymes, Aspergillus brasiliensis , A. fumigatus var. niveus , Trichoderma reesei and Talaromyces sp. were co-cultivated on sugarcane bagasse modified in the lignin synthesis pathway. This bagasse was pretreated with piperonilic acid (PIP) and methylenedioxycinnamic acid (MDCA).

RESULTS: The enzymatic cocktail produced by the co-culture showed the highest hydrolysis efficiency. The best hydrolysis condition was at $50^{\circ} \mathrm{C}$ and $\mathrm{pH}$ 4.0. Talaromyces sp. and T. reesei demonstrated antagonism only between them.

CONCLUSION: Enzymatic cocktails produced through the co-cultivation of filamentous fungi are a concrete step towards increasing yields for the $2 \mathrm{G}$ ethanol industry.

\section{Statement Of Novelty}

The global economy is dependent on unsustainable fossil fuels. Climate change is an indisputable threat to humanity and societies must transition to sustainable energy sources. The second-generation (2G) ethanol is an alternative, but high production costs still impede the scaling out of this technology. Biomass pretreatment and the production of lignocellulolytic enzymes are the most costly steps. This study approaches both issues. The co-cultivation of four fungi produced a multi-enzyme cocktail capable of degrading lignocellulosic biomass (sugarcane bagasse). The pretreatment utilized has been co-opted from studies on the effects of allelochemicals in plant development. Lignin synthesis inhibitors have shown to disrupt lignin deposition in the plant cell wall and might represent a new biochemical pretreatment for lignocellulosic materials.

\section{Introduction}

The planetary boundaries for a safe and sustainable human existence were first established in 2009 [1]. They were revisited and updated in 2015 [2] ahead of the COP21 that culminated in the Paris Agreement [3]. Because of the Covid-19 pandemic, the global primary energy consumption declined $4.5 \%$ and carbon emissions tanked $6.3 \%$ in 2020 [4]. However, more than $80 \%$ of the world's energy matrix still derives from fossil fuels [5]. The negotiations from COP26 have fallen short [6, 7] and the $1.5^{\circ} \mathrm{C}$ Pathway is no longer attainable by 2050 [8]. Indeed, the demands for oil and gas are expected to peak in the coming decades [8]. The consumption of fossil fuels is the largest source of greenhouse gases (GHGs) emissions [9], and climate change is no longer a grim possibility, but an alarming reality [10]. The effects of a warmer climate are wide ranging, as they accelerate the loss of biodiversity, desertification, sea level rising, to list a few [11, 12]. Renewable energy sources are then necessary [13] and the second generation $(2 \mathrm{G})$ ethanol is one alternative [14].

$2 \mathrm{G}$ ethanol is produced through the enzymatic hydrolysis of lignocellulosic biomass [15]. This biomass (i.e. the plant cell wall) is constituted primarily of cellulose, hemicellulose, and lignin [16]. Through pretreatments and enzymatic reactions, the plant cell wall can be broken down into fermentable sugars (i.e. saccharification), that in turn are converted to ethanol (i.e. fermentation) [17]. But, lignocellulosic materials are recalcitrant and present variable composition among different plant species $[18,19]$. Tailored pretreatments and heterogeneous enzymatic cocktails are then needed for efficient biomass degradation $[20,21]$.

Traditional biomass pretreatments often employ harsh and costly physicochemical conditions, as they use concentrated acid or alkaline solutions and other solvents [22]. Lignin synthesis inhibitors, such as piperonilic acid (PIP) and methylenedioxycinnamic acid (MDCA), represent a viable and ecofriendly pretreatment alternative. These compounds inhibit the phenylpropanoid pathway, ultimately reducing the amount of lignin in the plant cell wall [23]. PIP irreversibly blocks cinnamate 4-hydroxylase and MDCA competitively inhibits 4-coumarate:CoA ligase [24, 25]. As the lignin synthesis is disrupted, the use of such inhibitors is expected to increase biomass digestibility by loosening and exposing cellulose fibers.

The saccharification process comes after an effective pretreatment. Lignocellulolytic enzymes derived from fungi are extensively used in this step [26]. Axenic fungal cultures produce crude extracts [27] or heterologous proteins [28] that are capable of degrading different biomass sources. Several fungi can be grown separately and have their extracts subsequently combined into multi-enzyme cocktails as well [29]. A cost-effective alternative is the coculture of fungi [30], an approach that is also called co-cultivation or microbial/fungal consortium [31, 32]. These consortia grow synergistically and produce high-performance enzymatic cocktails [33] along with several secondary metabolites of value to other industries [34].

Aspergillus and Trichoderma species are model organisms in the production of lignocellulolytic enzymes [35]. They secrete cellulases and hemicellulases that can be produced in large-scale [36, 37], but oftentimes do not produce key accessory enzymes in sufficient amounts [38]. Here, we aimed to produce an enzymatic cocktail via the co-cultivation of Trichoderma reesei,Aspergillus brasiliensis, Aspergillus fumigatus var. niveus, and Talaromyces sp. The multi-enzyme cocktail was applied in the saccharification of sugarcane bagasse pretreated with piperonilic acid (PIP) and methylenodyoxicinnamic acid (MDCA). 


\section{Materials And Methods}

\subsection{Fungal strains}

The strains are deposited at the fungal collection of the Microbiology and Cell Biology laboratory at FFCL/USP-RP, Ribeirão Preto, Brazil. We used the model species T. reesei RUT C30 (ATCC 56765), A. brasiliensis and A. fumigatus var. niveus [39], and a putative new species of Talaromyces sect. Talaromyces.

\subsection{Confrontation assay}

A confrontation assay was conducted to analyze the growth and behavior of the fungal strains when coexisting in the same environment. The assays used Petri dishes with PDA culture media cut in a cross format. Each fungal species was inoculated in each tip of the cross and in the center of it, leaving one of the tips without any fungi serving as an experimental control.

\subsection{Optimization of enzyme extract production}

The fungal strains were cultivated in $50 \mathrm{~mL}$ of Minimum Media (composed of trace elements and nitrate salts, $\mathrm{pH}=6.5)$ [35], with $1 \%$ of biomass (0.5 $\mathrm{g}$ of in natura sugarcane bagasse), in duplicate. A suspension of spores $\left(10^{7}\right)$ was inoculated, and the flasks were incubated at $30{ }^{\circ} \mathrm{C}, 120 \mathrm{rpm}$, for 5 days. Then, $10 \mathrm{~mL}$ of the extract was centrifuged at $4.000 \mathrm{rpm}$ and the supernatant was collected and stored at $4{ }^{\circ} \mathrm{C}$.

\subsection{Total protein determination}

Total protein determination followed the modified method of Bradford [40]. The procedure was performed in a 96-well plate, in triplicates. Each reaction had a total of $200 \mu \mathrm{L}$, with $40 \mu \mathrm{L}$ of the Coomassie Brilliant Blue BG-250 (BioRad®) reagent and $160 \mu \mathrm{L}$ of the extract. The blank was made with $160 \mu \mathrm{L}$ of water and $40 \mu \mathrm{L}$ of the reagent only. The quantification was estimated by absorbance at $595 \mathrm{~nm}$. The standard curve was calculated using bovine serum albumin (Sigma). The protein unit was defined as $\mu \mathrm{g}$ of protein $/ \mathrm{mL}$.

\subsection{SDS-PAGE}

Protein electrophoresis of the extracts was performed by the SDS-Page method. The $12 \%$ run gel and the $5 \%$ stacking gel were prepared in sufficient volume for a $1 \mathrm{~mm}$ plate. The enzyme extracts were concentrated in SpeedVac. $10 \mu \mathrm{L}$ of the extract and $10 \mu \mathrm{L}$ of the loading dye with 2 mercaptoethanol were mixed and boiled at $100^{\circ} \mathrm{C}$, applied in the gel, and run at $120 \mathrm{~V}$. After the run, the gel was colored with Coomassie Blue dye for later visualization of the bands.

\subsection{Enzymatic assays}

The enzymatic assays were performed in 96-well plates, with each reaction containing $10 \mu \mathrm{L}$ of $50 \mathrm{mM}$ sodium acetate buffer ( $\mathrm{pH}=5.0$ ), $15 \mu \mathrm{L}$ of enzyme extract, $25 \mu \mathrm{L}$ of substrate, and subsequent addition of $50 \mu \mathrm{L}$ of 3,5-dinitrosalicylic acid (DNS), or $\mathrm{Na}_{2} \mathrm{CO}_{3}$, totaling $100 \mu \mathrm{L}$. Natural substrates were used for cellulases (1\% CMC and 1\% Avicel), for xylanases (Xylan from Beechwood 1\%) and for xyloglucanases (Xyloglucan 0.5\%). Synthetic substrates were used for endo and exocellulases ( $2 \mathrm{mM}$ pnp- $\beta$-D-cellobioside) and for $\beta$-glucosidases ( $2 \mathrm{mM}$ pnp- $\beta$-D-glucopyranoside). The method from Miller [41] was used for the determination of reducing sugars released by the degradation of natural substrates. For the synthetic substrates, the reactive agent used was $0.2 \mathrm{M} \mathrm{Na}_{2} \mathrm{CO}_{3}$. The reactions were incubated at $50{ }^{\circ} \mathrm{C}$ for $30 \mathrm{~min}$, and then the revealing reagents were added. In the DNS assay, after its addition to the reactions, they were submitted for another heating at $98{ }^{\circ} \mathrm{C}$ for $5 \mathrm{~min}$. There was a blank reaction for each enzymatic reaction. The plates were read at $540 \mathrm{~nm}$ and $410 \mathrm{~nm}$ for the natural and synthetic substrates, respectively.

The standard curve was made using cellobiose, xylose or glucose to calculate the enzymatic activity on natural substrates. Paranitrophenol (pnp) was used in the standard curve for the synthetic substrates. The unit of enzyme activity was defined as the amount of enzyme able to release $1 \mu$ mol of product per minute under the assay conditions.

\subsection{Biomass hydrolysis by the enzymatic cocktail produced from fungi grown in sugarcane bagasse with modified lignin synthesis pathway}

\subsubsection{Production of extracts from each sample and its combinations}

Separate enzyme extracts were prepared for each fungus as described above, in item 2.4. The fungi were cultivated in three distinct types of sugarcane bagasse. Two types were pretreated and the third type was in natura (non-treated) bagasse used for the experimental control. The pretreated bagasse was obtained with the use of lignification inhibitors, piperonyl acid (PIP) and methylenedioxycinnamic acid (MDCA).

The enzymatic extracts had their total proteins quantified and further analyzed on polyacrylamide gel as described above (item 2.6).

This initial hydrolysis was performed in triplicates, in $1 \mathrm{~mL}$ 96-well plates containing $500 \mu \mathrm{L}$ of $50 \mathrm{mM}$ sodium acetate buffer ( $\mathrm{pH}=5.0)$ and $500 \mu \mathrm{L}$ of enzyme extract and $3 \%$ sugarcane bagasse. The extracts of different fungi were combined as follow: $A$. brasiliensis + T. reesei; $A$. fumigatus var. niveus + T. reesei; Talaromyces sp. + T. reesei; $A$. brasiliensis + A. fumigatus var. niveus + Talaromyces sp.; A. brasiliensis + A. fumigatus var. niveus + T. reesei + Talaromyces sp. The volumes of each extract in the reaction were proportional to the number of fungi mixed in, in order to totalize $500 \mu \mathrm{L}$ of extract 
(e.g. $250 \mu \mathrm{L}$ of $A$. fumigatus var. niveus extract $+250 \mu \mathrm{L}$ of $T$. reesei extract). For each reaction, a blank was determined, using water instead of the enzyme extract.

The plates were incubated under agitation at $50{ }^{\circ} \mathrm{C}$, for $24 \mathrm{~h}$. At the end, the plates were centrifuged at $4,000 \mathrm{rpm}$, for 10 minutes. Afterward, the released reducing sugars were measured by the DNS method as described above (item 2.7).

\subsubsection{Co-culture}

The co-cultures followed the steps mentioned in items 2.3 and 2.7.1 and used the same three different types of bagasse mentioned above. For the cocultures, the fungi were inoculated together using an equal volume of the spore solution of each fungus, for a total of $1 \mathrm{~mL}$ of inoculum. In duplicate, there were five combinations for each type of bagasse: $A$. brasiliensis + T. reesei; $A$. fumigatus var. niveus + T. reesei; Talaromyces sp. + T. reesei; $A$. brasiliensis + A. fumigatus var. niveus + Talaromyces sp.; A. brasiliensis + A. fumigatus var. niveus + T. reesei + Talaromyces sp.

The samples also had their total proteins quantified and analyzed on SDS-PAGE gel. The hydrolysis and enzymatic assays were performed as described above.

\subsection{Optimization of hydrolysis assays for the produced cocktail}

The optimal $\mathrm{pH}$ and temperature of the best performing cocktail were determined by a similar plate assay as described in 2.8 . For the optimal $\mathrm{pH}$, the hydrolysis assays were conducted in a $\mathrm{pH}$ range of $3-8$, using a Mcllvaine buffer. For the optimal temperature, the assays were conducted in a range of $30-80^{\circ} \mathrm{C}$, with an interval of $10^{\circ} \mathrm{C}$. The released reducing sugars were determined by the DNS method from Miller, as described above.

\section{Results And Discussion}

\subsection{Standardization of the enzymatic production}

\subsubsection{Protein profile}

A. brasiliensis, $A$. fumigatus var. niveus, and Talaromyces sp., had a similar protein amount for all extracts when the same volume was used in the reaction. The exception was $T$. reesei, which secreted slightly higher amounts of protein (Fig. 1a). The same was observed in the co-cultivation, indicating that the sugarcane bagasse induced a similar amount of proteins in all situations (Fig. 1b).

All these data were validated by SDS-PAGE (data not shown). However, it was observed, by SDS-PAGE, a different protein profile among different extracts, which allows us to infer that the substrate (sugarcane bagasse) differentially induces the production of proteins across them.

\subsubsection{Enzymatic activity profile}

The screening of enzymatic activity counts as an important analysis to achieve a catalytic profile from the microorganisms [42]. The substrates chosen in this investigation, xylan from beechwood, avicel, carboximetilcellulose (CMC), xyloglucan, pnp- $\beta$-D-glucopyranoside and pnp- $\beta$-D-cellobioside, represented a good diversity to screen the main catalysts that attack the sugarcane bagasse cell wall [43].

A. brasiliensis and A. fumigatus v. niveus had hemicellulolytic, but low cellulolytic activity (Table 1). Although A. brasiliensis is very similar to $A$. niger, its glucosidase activity is very low, demonstrating the need to add some other good producer in the enzymatic blend. T. reesei RutC30 is known to secret cellulolytic enzymes $[44,45]$. Talaromyces sp. presented a considerable activity of cellulases and hemicellulases as well (Table 1 ).

Fungi from the section Nigri are known to produce xylanases and $\beta$-glucosidases $[46,47]$. So, $A$. brasiliensis was added to the cocktail to supplement the cellulolytic cocktail secreted by $T$. reesei. A. fumigatus var. niveus is a good hemicellulase producer as well [48]. Talaromyces sp. was added because several species of this genus secrete hemicellulases and cellulases (including $\beta$-glucosidades) $[49,50,51]$.

\subsection{Confrontation assays for co-culture validation}

Prior to the co-culture, the fungi were evaluated for their ability to grow together. $A$. brasiliensis presented high sporulation and very fast growth like other black fungi such as $A$. niger, $A$. saccharolyticus and $A$. carbonarius [52]. Plates inoculated with $A$. brasiliensis were totally covered, including the tip used as control. The colonies of $A$. fumigatus var. niveus and T. reesei were not inhibited (Online Resource 1). Theconfrontation assayof Talaromyces sp.was performed without inoculating $A$. brasiliensis because of its very fast growth. All fungi grew well and $A$. fumigatus var. niveus grew normally in the presence of Talaromyces sp. However, Talaromyces sp. exhibited a small inhibition halo when in contact with $T$. reesei, indicating a possible competition between them (Online Resource 1).

\subsection{Hydrolysis of the pretreated (lignin-inhibited) sugarcane bagasse}

Under co-cultivation, the cocktails produced on PIP-pretreated bagasse promoted hydrolysis under all conditions (Fig. 2a). The cocktail produced by Talaromyces sp. + T. reesei exhibited the highest release of reducing sugars when applied to the MDCA-pretreated bagasse (Fig. 2b). The MDCA pretreatment probably made the cellulose skeleton more accessible to cellulolytic enzymes. 
The cocktail produced by Talaromyces sp. with T. reesei, on the control and MDCA-pretreated bagasse, exhibited lower levels of hydrolysis when applied onto treated and untreated bagasse. Co-cultures of $T$. reesei with Aspergillus species have presented low hydrolysis efficiency before [52]. This could be explained by the possible competition between these two fungi (as observed in the confrontation assay), or by the production of holocellulolytic enzymes containing carbohydrate-binding modules (CBMs). Although CBMs are important to hydrolytic activity [53], they can also decrease enzymatic hydrolysis by causing the enzymes to adhere to lignin [54]. The control (in natura bagasse) and the MDCA bagasse could represent a lignin-rich surface and a substrate where lignin is more readily available, respectively.

The co-cultivation of all fungi grown in both PIP- and MDCA-pretreated bagasse showed good hydrolytic capacity (Fig. 2c). Microbial co-cultivation can be a cost effective alternative for industrial processes [55]. Co-culturing fungi decreases enzyme production costs, as inputs (reagents, electricity and humanpower) are better used [56]. Microbial consortia also minimizes the incubation/fermentation time while maintaining high levels of enzyme production [57].

Combining enzymatic extracts produced by the fungi after being cultivated separately exhibited similar results and validated the efficiency of the cocultivation strategy. The extracts obtained from fungi grown in PIP-pretreated bagasse had the best results (approximately $1.1 \mu \mathrm{mol} / \mathrm{mL}$ ). The combination of all extracts released $2 \mu \mathrm{mol} / \mathrm{mL}$ of reducing sugars from the MDCA-pretreated bagasse (Fig. 3a). The combination of Talaromyces sp. and $T$. reesei extracts had a higher hydrolysis efficiency in the extracts produced using the PIP-pretreated bagasse. The extracts produced using the control and MDCA-pretreated bagasse yielded, respectively, $0.9 \mu \mathrm{mol} \mathrm{mL}$ and $1.3 \mu \mathrm{mol} / \mathrm{mL}$ of released reducing sugars from the MDCA-pretreated bagasse. These results are quite higher than those from the co-cultivation, which corroborates the possible competition between these two strains when grown together. As the fungi grew separately under ideal conditions (i.e. without interspecific competition), they might have produced extracts with higher amounts of holocellulolytic enzymes that could yield a more efficient hydrolysis when combined (Fig. 2b). Although the combination of the separate extracts exhibited similar results to the co-cultivation, the latter strategy is still more advantageous as it is more cost-effective.

The sugarcane pretreatments with lignin synthesis inhibitors alter the structure and amount of lignin, but the concentration of cellulose, hemicellulose and other components remains intact. Some varieties of sugarcane also have a modified concentration of other plant cell wall components. Applying the PIP- and MDCA-pretreatments on cellulose-rich sugarcane varieties, such as the energy cane [58], would be an interesting strategy for the bioethanol industry. Combining these technologies with the use holocellulolytic cocktails produced through the co-cultivation of fungi can only augment the current $2 \mathrm{G}$ bioethanol industrial processes.

\subsection{Optimization of hydrolysis of the co-cultured PIP-extract}

The co-cultivation of $A$. brasiliensis, $A$. fumigatus var. niveus, $T$. reesei and Talaromyces sp.in submerged fermentation using PIP-pretreated sugarcane bagasse as the only carbon source, presented the best hydrolysis efficiency in all bagasse (Fig. $3 a$ ). At $50^{\circ} \mathrm{C}$, the optimal pH was 4.0 , showing a prominent increase in the hydrolysis efficiency of all bagasse tested in this study (Fig. 4a and Fig. 4b).

\section{Conclusions}

The co-cultivation of fungal species in the pretreated bagasse was confirmed as a good alternative for the enzymatic production, leading to obtaining a cocktail capable of hydrolyzing different types of biomass efficiently. Thus, this strategy together with biomass pretreatments (PIP and MDCA), that favor the accessibility of enzymes to the cellulose skeleton, can increase the efficiency of this bioprocess. However, the efficiency of extract combinations in an enzyme blend is not discarded, and it is a good alternative for the hydrolysis of industrial waste. Finally, the optimization of the physicochemical conditions for the enzymatic blends acting in the different types of industrial processes can lead to an increase in its efficiency, adding even more value to the desired product.

\section{Declarations}

\section{Funding}

This work was supported by National Council for Scientific and Technological Development, CNPq (Grant numbers number 2017/1534), Fundação de Amparo à Pesquisa do Estado de São Paulo (Grant number 2017/09000-4) and Coordination of Superior Level Staff Improvement, CAPES.

\section{Conflicts of interests}

The authors have no conflicts of interest to declare that are relevant to the content of this article.

\section{Author contributions}

All authors contributed to the study conception and design. Material preparation, data collection and analysis were performed by Yuri Heck da Silva, Tássio Brito de Oliveira and Rosymar Coutinho de Lucas. The first draft of the manuscript was written by Yuri Heck da Silva and all authors commented on previous versions of the manuscript. All authors read and approved the final manuscript.

\section{Data Availability}


All data generated or analysed during this study are included in this published article, and its supplementary information file.

Acknowledgements

Authors are thankful to the National Council for Scientific and Technological Development (CNPq) and Fundação de Amparo à Pesquisa do Estado de São Paulo for funding this study. We thank Dr. Wanderley Dantas dos Santos, from the State University of Maringá, for gently providing the pretreated sugarcane bagasse. We also thank Dr. Carlos Alberto Martinez y Huaman, from FFCLRP, University of São Paulo, for providing the soil samples from which Talaromyces sp. was isolated.

\section{References}

1. Rockström, J., Steffen, W., Noone, K., Persson Å., III Chapin, F. S., Lambin, E., Lenton, T. M., Scheffer, M., Folke, C., Schellnhuber, H. J., Nykvist, B., de Wit, C. A., Hughes, T., van der Leeuw, S., Rodhe, H., Sörlin, S., Snyder, P. K., Costanza, R., Svedin, U., Falkenmark, M., Karlberg, L., Corell, R. W., Fabry, V. J., Hansen, J., Walker, B., Liverman, D., Richardson, K., Crutzen, P., Foley, J.: Planetary boundaries: exploring the safe operating space for humanity. Ecology and Society 14(2): 32 (2009).

2. Steffen, W., Richardson, K., Rockström, J., Cornell, S. E., Fetzer, I., Bennett, E. M., Biggs, R., Carpenter, S. R., de Vries, W., de Wit, C. A., Folke, C., Gerten, D., Heinke, J., Mace, G. M., Persson, L. M., Ramanathan, V., Reyers, B., Sörlin, S.: Planetary boundaries: guiding human development on a changing planet. Science 347(6223): 1259855 (2015). https://doi.org/10.1126/science.1259855

3. Savaresi, A.: The Paris Agreement: a new beginning? Journal of Energy \& Natural Resources Law 34:1, 16-26 (2016). https://doi.org/10.1080/02646811.2016.1133983

4. bp Statistical review of world energy $2021,70^{\text {th }}$ edition. bp p.l.c. https://www.bp.com/content/dam/bp/businesssites/en/global/corporate/pdfs/energy-economics/statistical-review/bp-stats-review-2021-full-report.pdf (2021). Accessed 01 December 2021

5. Ritchie, H., Roser, M.: Energy. Our World in Data. https://ourworldindata.org/energy (2020). Accessed 01 December 2021

6. Sheather, J.: The conflicts that killed COP26. The BMJ 375:n2798 (2021). https://doi.org/10.1136/bmj.n2798

7. Issa, R., Krzanowski, J.: Finding hope in COP26. The BMJ 375:n2940 (2021). https://doi.org/10.1136/bmj.n2940

8. Global energy perspective 2021. McKinsey \& Company.

https://www.mckinsey.com/ /media/McKinsey/Industries/Oil\%20and\%20Gas/Our\%20Insights/Global\%20Energy\%20Perspective\%202021/GlobalEnergy-Perspective-2021-final.pdf (2021). Accessed 01 December 2021

9. Emissions Gap Report 2021: The heat is on - a world of climate promises not yet delivered. United Nations Environment Programme. https://www.unep.org/resources/emissions-gap-report-2021 (2021). Accessed 01 December 2021.

10. Malhi, Y., Franklin, J., Seddon, N., Solan, M., Turner, M. G., Field, C. B., Knowlton, N.: Climate change and ecosystems: threats, opportunities and solutions. Philos. Trans. R. Soc. Lond. B. Biol. Sci. 375(1794): 20190104 (2020). https://doi.org/10.1098/rstb.2019.0104

11. Turner, M. G., Calder, W. J., Cumming, G. S., Hughes, T. P., Jentsch, A., LaDeau, S. L., Lenton, T. M., Shuman, B. N., Turetsky, M. R., Ratajczak, Z., Williams, J. W., Williams, A. P., Carpenter, S. R.: Climate change, ecosystems and abrupt change: science priorities. Philos. Trans. R. Soc. Lond. B. Biol. Sci. 375(1794): 20190105 (2020). https://doi.org/10.1098/rstb.2019.0105

12. Hooper-Bùi, L. M., Strecker-Lau, R. M., Stewart, D. M., Landry, M. J., Papillion, A. M., Peterson, S. N., Daniel, R. A.: Effects of sea-level rise on physiological ecology of populations of a ground-dwelling ant. PLoS One 15(4): e0223304 (2020). https://doi.org/10.1371/journal.pone.0223304

13. de Oliveira Noronha, M., Ruviaro Zanini, R., Mendonça Souza, A.: The impacto f electric generation capacity by renewable and non-renewable energy in Brazilian economic growth. Environ. Sci. Pollut. Res. Int. 26(32): 33236-33259 (2019). https://doi.org/10.1007/s11356-019-06241-4

14. de Almeida Scarcella, A. N., Machado Pasin, T., Coutinho de Lucas, R., Stropa Ferreira-Nozawa, M., Brito de Oliveira, T., Graça Contato, A., Grandis, A., Silveira Buckeridge, M., Teixeira de Moraes Polizeli, M. L.: Holocellulase production by filamentous fungi: potential in the hydrolysis of energy cane and other sugarcane varieties. Biomass Conv. Bioref. (2021). https://doi.org/10.1007/s13399-021-01304-4

15. Coutinho de Lucas, R., Brito de Oliveira, T., Sanitá Lima, M., Machado Pasin, T., de Almeida Scarcella, A. S., Prade, R. A., Segato, F. Teixeira de Moraes Polizeli, M. L.: Effect of enzymatic pretreatment of sugarcane bagasse with recombinant hemicellulase and esterase prior to the application of the cellobiohydrolase CBH I Megazyme®. Biomass Conv. Bioref. (2020). https://doi.org/10.1007/s13399-020-00719-9

16. Graça Contato, A., Brito de Oliveira, T., Mauro Aranha, G., Neiverth de Freitas, E., Vici, A. C., Vieira Nogueira, K. M., Coutinho de Lucas, R., de Almeida Scarcella A. S., Silveira Buckeridge, M., Nascimento Silva, R., Teixeira de Moraes Polizeli, M. L.: Prospection of fungal lignocellulolytic enzymes produced from Jatoba (Hymenaea courbaril) and Tamarind (Tamarindus indica) seeds: scaling for bioreactor and saccharification profile of sugarcane bagasse. Microorganisms 9(3): 533 (2021). https://doi.org/10.3390/microorganisms9030533

17. Coutinho de Lucas, R., Brito de Oliveira, T., Sanitá Lima, M., Machado Pasin, T. de Almeida Scarcella, A. S., Fraga Costa Ribeiro, L., Carvalho, C., de Lima Damásio, A. R., Silveira Buckeridge, M., Prade, R. A., Segato, F., Teixeira de Moraes Polizeli, M. L.: the profile secretion of Aspergillus clavatus: different pre-treatments of sugarcane bagasse distinctly induces holocellulases for the lignocellulosic biomass conversion into sugar. Renewable Energy 165, 748-757 (2021). https://doi.org/10.1016/j.renene.2020.11.072

18. Schmitz, E., Nordberg Karlsson, E., Adlercreutz, P. Ultrasound assisted alkaline pre-treatment efficiently solubilises hemicellulose from oat hulls. Waste Biomass Valor. 12:5371-5381 (2021). https://doi.org/10.1007/s12649-021-01406-0 
19. Oliveira, D. M., Mota, T. R., Grandis, A., de Morais, G. R., Coutinho de Lucas, R., Teixeira de Moraes Polizeli, M. L., Marchiosi, R., Silveira Buckeridge, M., Ferrarese-Filho, O., dos Santos, W. D.: Lignin plays a key role in determining biomass recalcitrance in forage grasses. Renewable Energy 147 , 2206-2217 (2020). https://doi.org/10.1016/j.renene.2019.10.020

20. de Araújo Padilha, C. E., da Costa Nogueira, C., Ribeiro Alves Alencar, B., Barbosa Silva de Abreu, Í, Damilano Dutra, E., Chavez Ruiz, J. A., Fabiano de Santana Souza, D., Silvino dos Santos, E.: Production and application of lignin-based chemicals and materials in the cellulosic ethanol production: an overview on lignin closed-loop biorefinery approaches. Waste Biomass Valor. 12:6309-6337 (2021). https://doi.org/10.1007/s12649-021-014555

21. Teixeira de Moraes Polizeli, M. L., Favarin Somera, A., Coutinho de Lucas, R., Stropa Ferreira Nozawa, M., Michelin, M.: Enzymes involved in the biodegradation of sugarcane biomass: challenges and perspectives. In: Buckeridge, M., de Souza, A. (eds.) Advances of basic science for second generation bioethanol from sugarcane, pp 55-79. Springer, Cham (2017). https://doi.org/10.1007/978-3-319-49826-3_5

22. Sharma, H. K., Xu, C., Qin, W.: Biological pretreatment of lignocellulosic biomass for biofuels and bioproducts: an overview. Waste Biomass Valor. 10, 235-251 (2019). https://doi.org/10.1007/s12649-017-0059-y

23. Ferro, A. P., Marchiosi, R., de Cássia Siqueira-Soares, R., Aparecida Bonini E., Lucio Ferrarese, M. L., Ferrarese-Filho, O.: Effects of cinnamic and ferulic acids on growth and lignification of maize roots. Journal of Allelochemical Interactions 1(2): 29-38 (2015)

24. Barbosa Lima, R., Salvador V. H., Dantas dos Santos, W., Bubna, G. A., Finger-Teixeira, A., Soares, A. R., Marchiosi, R., Lucio Ferrarese, M. L., Ferrarese-Filho, 0. : Enhanced ligin monomer production caused by cinnamic acid and its hydroxylated derivatives inhibits soybean root growth. PLos One 8(12): e80542. https://doi.org/10.1371/journal.pone.0080542

25. Bubna, G. A., Barbosa Lima, R., Lucca Zanardo, D. Y., Dantas dos Santos, W., Lucio Ferrarese, M. L., Ferrarese-Filho, O.: Exogenous caffeic acid inhibits the growth and enhances the lignification of the roots of soybean (Glycine max). Journal of Plant Physiology 168: 1627-1633 (2011). https://doi.org/10.1016/j.jplph.2011.03.005

26. Segato, F., de Lima Damásio, A. R., Coutinho de Lucas, R., Squina, F. M., Prade, R. A.: Genomics review of holocellulose deconstruction by aspergilli. Microbiol Mol Biol Rev. 78(4): 588-613 (2014). https://doi.org/10.1128/MMBR.00019-14.

27. Machado Pasin, T., de Almeida Scarcella, A. S., Brito de Oliveira, T., Coutinho de Lucas, R., Cereia, M., Betini, J. H. A., Teixeira de Moraes Polizeli, M. L.: Paper industry wastes as carbon sources for Aspergillus species cultivation and production of an enzymatic cocktail for biotechnological applications. Industrial Biotechnology 16(2): 56-60 (2020). https://doi.org/10.1089/ind.2020.29201.tmp

28. Leal Vitcosque, G., Fraga Costa Ribeiro, L., Coutinho de Lucas, R., da Silva, T. M., Ferreira Ribeiro, L., de Lima Damásio, A. R., Sanchez Farinas, C., Zorzetto Lopes Gonçalves, A., Segato, F., Silveira Buckeridge, M., Jorge, J. A., Teixeira de Moraes Polizeli, M. L.: The functional properties of a xyloglucanase (GH12) of Aspergillus terreus expressed in Aspergillus nidulans may increase performance of biomass degradation. Appl Microbiol Biotechnol 100, 9133-9144 (2016). https://doi.org/10.1007/s00253-016-7589-2

29. Soares Cardoso, W., de Freitas Soares F. E., Viana Queiroz, P., Peterlini Tavares, G., Almeida Santos, F., Leite Sufiate, B., Megumi Kasuya, M. C., de Queiroz, J. H.: Minimum cocktail of cellulolytic multi-enzyme complexes obtained from white rot fungi via solid-state fermentation. 3 Biotech 8(1): 46 (2018). https://doi.org/10.1007/s13205-017-1073-2

30. Sanitá Lima, M., de Lima Damásio, A. R., Crnkovic, P. M., Pinto, M. R., da Silva, A. M., da Silva, J. C. R., Segato, F., Coutinho de Lucas, R., Jorge, J. A., Teixeira de Moraes Polizeli, M. L.: Co-cultivation of Aspergillus nidulans recombinant strains produces an enzymatic cocktail as alternative to alkaline sugarcane bagasse pretreatment. Front. Microbiol. 7:583. https://doi.org/10.3389/fmicb.2016.00583

31. Sperandio, G. B., Ximenes Ferreira Filho, E.: An overview of Trichoderma reesei co-cultures for the production of lignocellulytic enzymes. Appl. Microbiol. Biotechnol. 105(8): 3019-3025 (2021). https://doi.org/10.1007/s00253-021-11261-7

32. Zoglowek, M., Hansen, G. H., Lübeck, P. S., Lübeck, M.: Fungal consortia for conversion of lignocellulose into bioproducts. In: Silva, R. N. (ed.) Mycology: current and future developments. Fungal biotechnology for biofuel production, pp 329-364. Bentham Science Publishers Ltd. (2016).

33. de Almeida Scarcella, A. S., Machado Pasin, T., Brito de Oliveira, T., Coutinho de Lucas, R., Stropa Ferreira-Nozawa, M., Neiverth de Freitas, E., Vici, A. C., Silveira Buckeridge, M., Michelin, M., Teixeira de Moraes Polizeli, M. L.: Saccharification of different sugarcane bagasse variaties by enzymatic cocktails produced by Mycothermus thermophilus and Trichoderma reesei RP698 cultures in agro-industrial residues. Energy 226, 120360 (2021). https://doi.org/10.1016/j.energy.2021.120360

34. Oppong-Danquah, E., Budnicka, P., Blümel, M., Tasdemir, D.: Design of fungal co-cultivation based on comparative metabolomics and bioactivity for discovery of marine fungal agrochemicals. Mar. Drugs 18(2): 73 (2020). https://doi.org/10.3390/md18020073

35. Segato, F., de Lima Damásio, A. R., Gonçalves, T. A., Coutinho de Lucas, R., Squina, F. M., Decker, S. R., Prade, R. A.: High-yield secretion of multiple cliente proteins in Aspergillus. Enzyme and Microbial Technology 51(2): 100-106 (2012). https://doi.org/10.1016/j.enzmictec.2012.04.008

36. da Silva, T. M., Costa Pessela, B., da Silva, J. C. R., Sanitá Lima, M., Jorge, J. A., Guisan, J. M., Teixeira de Moraes Polizeli, M. L.: Immobilization and high stability of na extracellular $\beta$-glucosidase from Aspergillus japonicus by ionic interactions. Journal of Molecular Catalysis B: Enzymatic 104, 95-100 (2014). https://doi.org/10.1016/j.molcatb.2014.02.018

37. Machado Benassi, V., da Silva, T. M., Costa Pessela, B., Guisan, J. M., Mateo, C., Sanitá Lima, M., Jorge, J. A., Teixeira de Moraes Polizeli, M. L.: Immobilization and biochemical properties of a $\beta$-xylosidase activated by glucose/xylose from Aspergillus niger USP-67 with transxylosylation actvity. Journal of Molecular Catalysis B: Enzymatic 89, 93-101 (2013). https://doi.org/10.1016/j.molcatb.2012.12.010

38. Machado Benassi, V., Coutinho de Lucas, R., Jorge, J. A., Teixeira de Moraes Polizeli, M. L.: Screening of thermotolerant and thermophilic fungi aiming $\beta$-xylosidase and arabinanase production. Brazilian Journal of Microbiology 45(4): 1459-1467 (2014).

Page 7/12 
39. Couger, B., Weirick, T., de Lima Damásio, A. R., Segato, F., Teixeira de Moraes Polizeli, M. L., de Almeida, R. S. C., Goldman, G. H., Prade, R. A. The genome of a thermo tolerant, pathogenic albino Aspergillus fumigatus. Front. Microbiol. 9:1827 (2018). https://doi.org/10.3389/fmicb.2018.01827

40. Bradford, M. M. A rapid and sensitive method for the quantitation of microgram quantities of protein utilizing the principle of protein-dye binding. Analyt. Biochem. 72, 248-254 (1976).

41. Miller, G.L. Use of Dinitrosalicylic Acid reagent for determination of reducing sugar. Anal Chem. 31, 426-429 (1959).

42. Fraga Costa Ribeiro, L., Ferreira Ribeiro, L., Jorge, J. A., Teixeira de Moraes Polizeli, M. L.: Screening of filamentous fungi for xylanases and cellulases not inhibited by xylose and glucose. Biotechnology Journal International 4(1), 30-39 (2013). https://doi.org/10.9734/BBJ/2014/6066

43. Machado Benassi, V., Coutinho de Lucas, R., Michelin, M., Jorge, J. A., Terenzi, H. F., Teixeira de Moraes Polizeli, M. L.: Production and action of an Aspergillus phoenicis enzymatic pool using different carbon sources. Braz. J. Food Technol. 15(3): 253-260 (2012). https://doi.org/10.1590/S198167232012005000019

44. Pagotto Borin, G., Sanchez, C. C., Pereira de Souza, A., Silva de Santana, E., Tieppo de Souza, A., Franco Paes Leme, A., Squina, F. M., Silveira Buckeridge, M., Goldman, G. H., Velasco de Castro Oliveira, J.: Comparative secretome analysis of Trichoderma reesei and Aspergillus niger during growth on sugarcane biomass. PLoS One 10(6): e0129275 (2015). https://doi.org/10.1371/journal.pone.0129275

45. Herpoël-Gimbert, I., Margeot, A., Dolla, A., Jan, G., Mollé, D., Lignon, S., Mathis, H., Sigoillot, J-C., Monot, F., Asther, M.: Comparative secretome analyses of two Trichoderma reesei RUT-C30 and CL847 hypersecretory strains. Biotechnology for Biofuels 1, 18 (2008). https://doi.org/10.1186/1754-6834-1-18

46. Betini, J. H. A., Michelin, M., de Carvaho Peixoto-Nogueira, S., Jorge, J. A., Terenzi, H. F., Teixeira de Moraes Polizeli, M. L.: Xylanases from Aspergillus niger, Aspergillus niveus and Aspergillus ochraceus produced under solid-state fermentation and their application in cellulose pulp bleaching. Bioprocess Biosyst Eng 32, 819-824 (2009). https://doi.org/10.1007/s00449-009-0308-y

47. Oriente, A., Tramontina, R., de Andrades, D., Henn, C., Silva, J. L. C., Simão, R. C. G., Maller, A., Teixeira de Moraes Polizeli, M. L., Kadowaki, M. K.: Characterization of a novel Aspergillus niger beta-glucosidase tolerant to saccharification of lignocellulosic biomass products and fermentation inhibitors. Chemical Papers 69(8): 1050-1057 (2015). https://doi.org/10.1515/chempap-2015-0111

48. de Carvalho Peixoto-Nogueira, S., Michelin, M., Betini, J. H. A., Jorge, J. A., Terenzi, H. F., Teixeira de Moraes Polizeli, M. L.: Production of xylanase by Aspergilli using alternative carbono sources: application of the crude extract on cellulose pulp biobleaching. Journal of Industrial Microbiology and Biotechnology 36(1): 149-155 (2009). https://doi.org/10.1007/s10295-008-0482-y

49. Méndez-Líter, J. A., de Eugenio, L. I., Nieto-Domínguez, M., Prieto, A., Martínez, M. J.: Hemicellulases from Penicillium and Talaromyces for lignocellulosic valorization: a review. Bioresour. Technol. $324: 124623$ (2021). https://doi.org/10.1016/j.biortech.2020.124623

50. Méndez-Líter, J. A., Nieto-Domínguez, M., Fernández de Toro, B., González Santana, A., Prieto, A., Asensio, J. L., Javier Cañada, F., de Eugenio, L. I., Martínez, M. J.: A glucotolerant $\beta$-glucosidase from the fungus Talaromyces amestolkiae and its conversion into a glycosynthase for glycosylation of phenolic compounds. Microb. Cell Fact. 19(1): 127 (2020). https://doi.org/10.1186/s12934-020-01386-1

51. Li, C-X., Zhao, S., Zhang, T., Xian, L., Liao, L-S., Liu, J-L., Feng, J-X.: Genome sequencing and analysis of Talaromyces pinophilus provide insights into biotechnological applications. Scientific Reports 7, 490 (2017). https://doi.org/10.1038/s41598-017-00567-0

52. Kolasa, M., Kiær Ahring, B., Stephensen Lübeck, P., Lübeck, M.: Co-cultivation of Trichoderma reesei RutC30 with three black Aspergillus strains facilitates efficient hydrolysis of pretretated wheat straw and shows promises for on-site enzyme production. Bioresour. Technol. 169, $143-148$ (2014). https://doi.org/10.1016/j.biortech.2014.06.082

53. Furtado, G. P., Santos, C. R., Cordeiro, R. L., Ribeiro, L. F., de Moraes, L. A. B., de Lima Damásio, A. R., Teixeira de Moraes Polizeli, M. L., Lourenzoni,

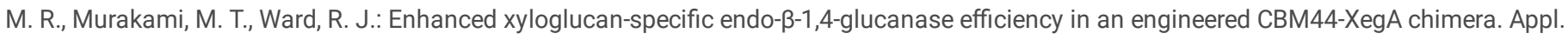
Microbiol. Biotechnol. 99, 5095-5107 (2015). https://doi.org/10.1007/s00253-014-6324-0

54. Várnai, A., Siika-aho, M., Viikari, L.: Carbohydrate-binding modules (CBMs) revisited: reduced amount of water counterbalances the need for CBMs. Biotechnol. Biofuels 6, 30 (2013). https://doi.org/10.1186/1754-6834-6-30

55. Bader, J., Mast-Gerlach, E., Popović, M. K., Bajpai, R., Stahl, U.: Relevance of microbial coculture fermentations in biotechnology. Journal of Applied Microbiology 109(2): 371-387 (2010). https://doi.org/10.1111/j.1365-2672.2009.04659.x

56. Intasit, R., Cheirsilp, B., Suyotha, W., Boonsawang, P.: Synergistic production of highly active enzymatic cocktails from lignocellulosic palm wastes by sequential solid state-submerged fermentation and co-cultivation of different filamentous fungi. Biochemical Engineering Journal 173,108086 (2021). https://doi.org/10.1016/j.bej.2021.108086

57. Yao, W., Nokes, S. E.: The use of co-culturing solid substrate cultivation and possible solutions to scientific challenges. Biofuels, Bioproducts and Biorefining 7(4): 361-372 (2013). https://doi.org/10.1002/bbb.1389

58. Matsuoka, S., Kennedy, A. J. dos Santos, E. G. D., Tomazela, A. L., Rubio, L. C. S.: Energy Cane: its concept, development characteristics, and prospects. Advances in Botany 2014, 597275 (2014). https://doi.org/10.1155/2014/597275

\section{Tables}

Table 1: Enzymatic profile of A. brasiliensis, A.fumigatus var. niveus and Talaromyces sp (120h of culture). 


\begin{tabular}{|llll|}
\hline Substrate & Activity $(\mathrm{U} / \mathrm{mL})$ & & \\
\hline & A. brasiliensis & A. fumigatus var. niveus & Talaromyces sp \\
\hline Xylan from beechwood & 0.30 & 3.24 & 5.5 \\
\hline Xyloglucan & $0 ., 06$ & 0.37 & 0.9 \\
\hline CMC & 0.04 & 0.05 & 0.08 \\
pnp- $\beta$-D-cellobioside & 0.004 & 0.01 & 0.02 \\
\hline$\beta-$ glucosidase & 0.03 & 0.09 & 0.03 \\
\hline
\end{tabular}

\section{Figures}

a
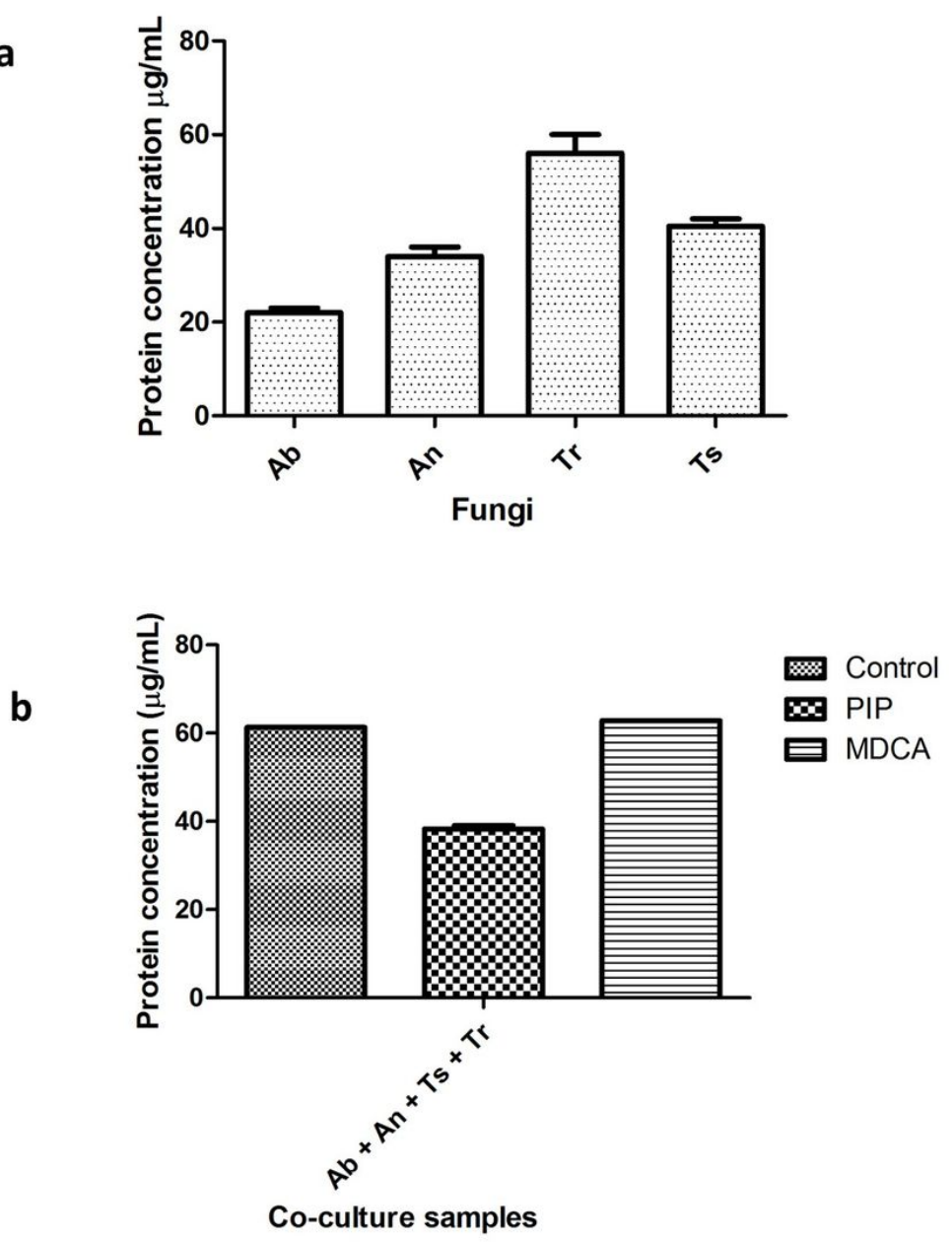

\section{Figure 1}

a Protein concentration of $A$. brasiliensis, A. fumigatus var. niveus and Talaromyces $s p$ (120h of culture) grown individually on control bagasse. $\mathbf{b}$ Protein concentration of $A$. brasiliensis, A. fumigatus var. niveus and Talaromyces sp (120h of culture) grown in co-cultivation on control and pretreated bagasse. 


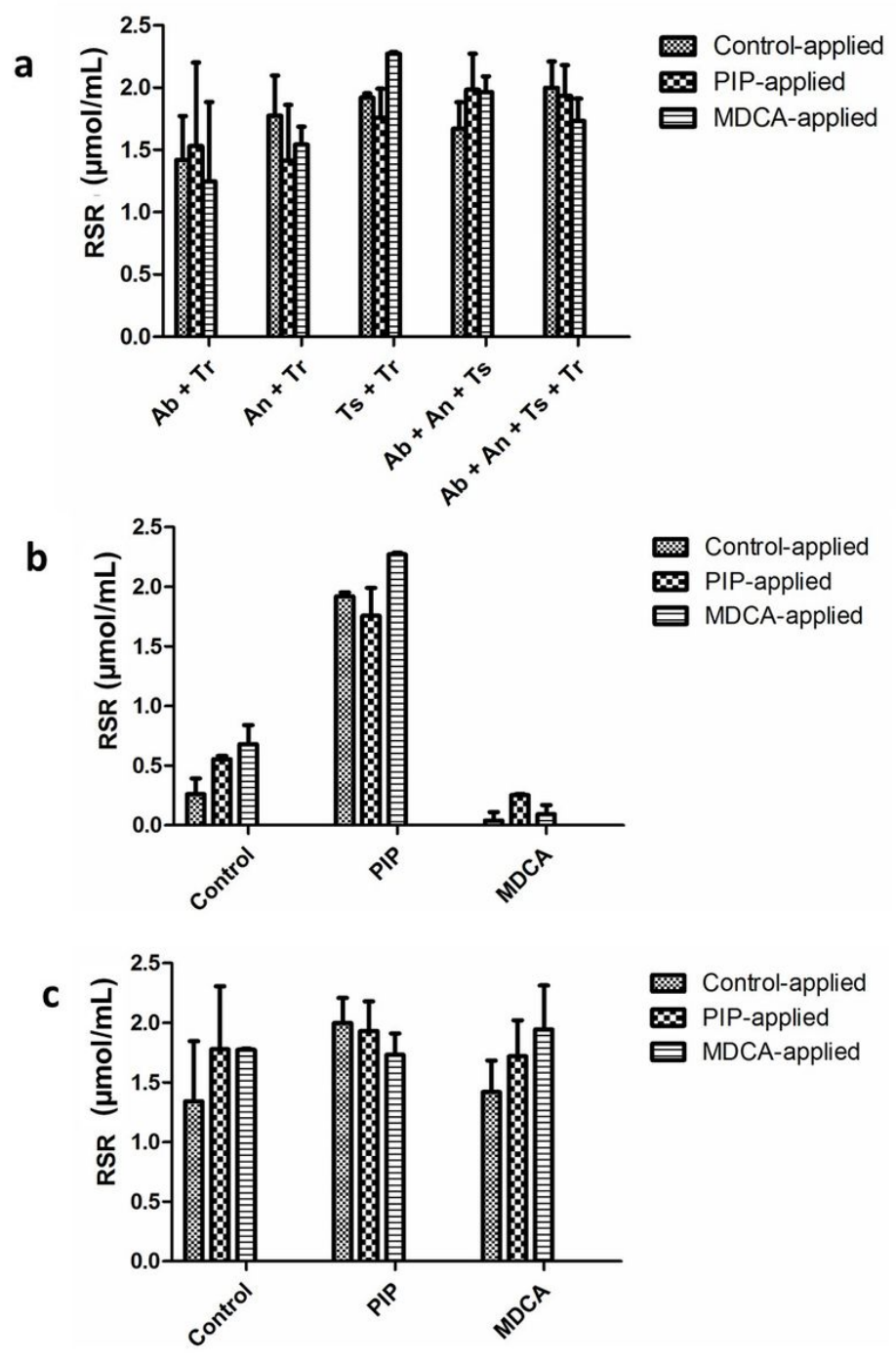

Figure 2

a Reducing sugars released in the hydrolysis of pretreated (PIP and MDCA) and control bagasse, using co-cultivation extracts produced in PIP bagasse. b Reducing sugars released using co-cultivation of Talaromyces sp. with T. reesei produced in PIP bagasse, MDCA and control. c Reducing sugars released using co-cultivation extracts of all fungi produced in PIP, MDCA and control bagasse. Ab- A. brasiliensis; An- A. niveus; Ts- Talaromyces sp.; Tr- T. reesei. 

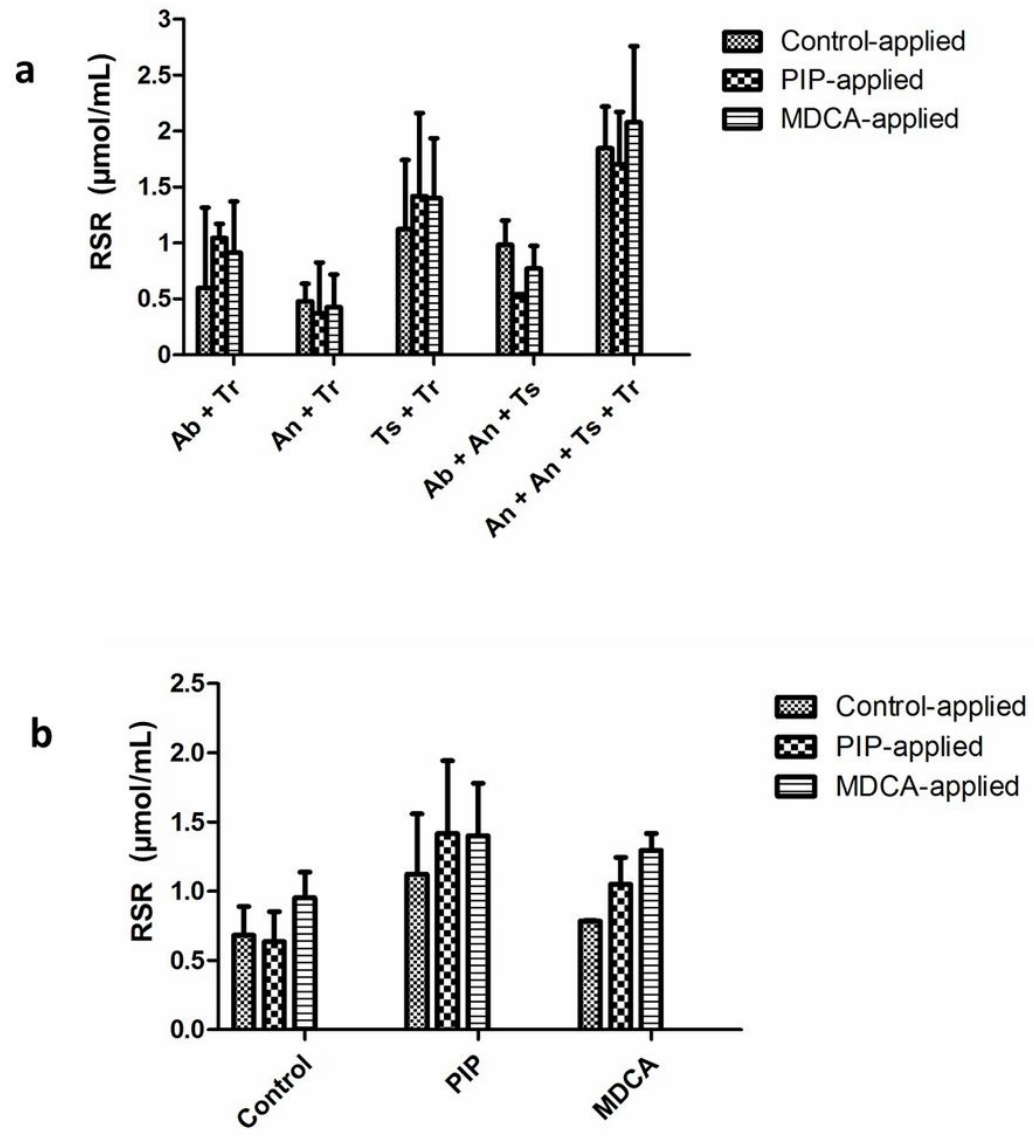

Figure 3

a Reducing sugars released in the hydrolysis of pretreated and control bagasse, using the combination of individual extracts produced in PIP bagasse. $\mathbf{b}$ Reducing sugars released using the combination of individual extracts of Talaromyces sp. and T. reesei produced in PIP bagasse, MDCA and control. Ab- A. brasiliensis, An- A. niveus; Ts- Talaromyces sp.; Tr- T. reesei. 
a

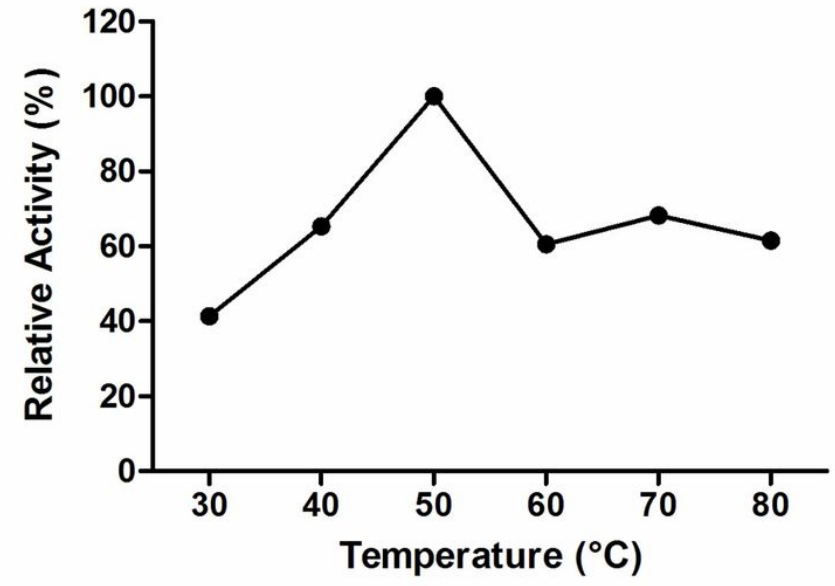

b

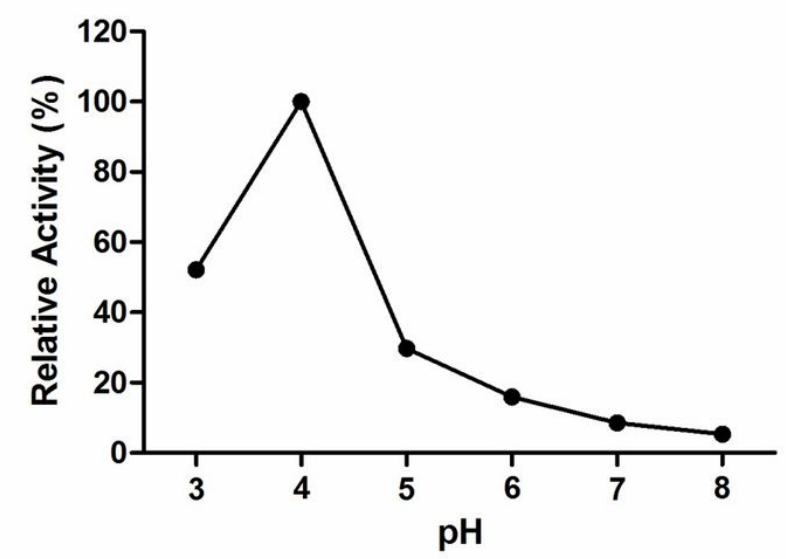

Figure 4

Best temperature and $\mathrm{pH}$ for the hydrolysis of control and pretreated bagasse, using the extract from the co-cultivation of all fungi from the cultivation in PIP bagasse.

\section{Supplementary Files}

This is a list of supplementary files associated with this preprint. Click to download.

- GRAPHICALABSTRACT.docx 